\title{
Offshore Geology and Geomorphology from Point Piedras Blancas to Pismo Beach, San Luis Obispo County, California
}

By Janet T. Watt, Samuel Y. Johnson, Stephen R. Hartwell, and Michelle Roberts

Pamphlet to accompany

Scientific Investigations Map 3327 


\section{U.S. Department of the Interior \\ SALLY JEWELL, Secretary}

\section{U.S. Geological Survey Suzette Kimball, Acting Director}

U.S. Geological Survey, Reston, Virginia: 2015

For more information on the USGS-the Federal source for science about the Earth, its natural and living resources, natural hazards, and the environment-visit http://www.usgs.gov/ or call 1-888-ASK-USGS (1-888-275-8747).

For an overview of USGS information products, including maps, imagery, and publications, visit http://www.usgs.gov/pubprod/.

To order USGS information products, visit http://store.usgs.gov/.

Any use of trade, firm, or product names is for descriptive purposes only and does not imply endorsement by the U.S. Government.

Although this information product, for the most part, is in the public domain, it also may contain copyrighted materials as noted in the text. Permission to reproduce copyrighted items must be secured from the copyright owner.

Suggested citation:

Watt, J.T., Johnson, S.Y., Hartwell, S.R., and Roberts, M., 2015, Offshore geology and geomorphology from Point Piedras Blancas to Pismo Beach, San Luis Obispo County, California: U.S. Geological Survey Scientific Investigations Map 3327, pamphlet 6 p., 6 sheets, scale 1:35,000, http://dx.doi.org/10.3133/sim3327.

ISSN 2329-132X (online) 


\section{Contents}

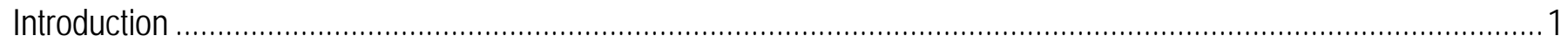

Map Units

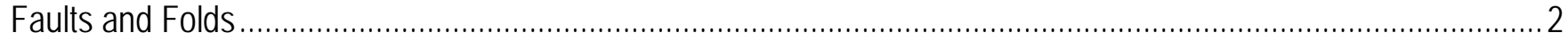

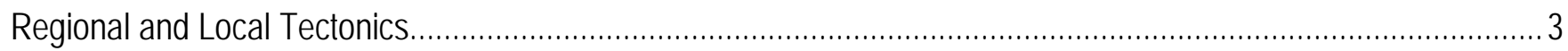

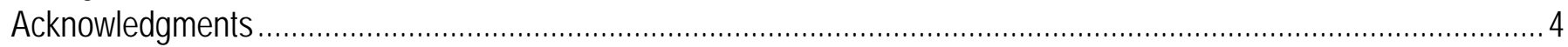

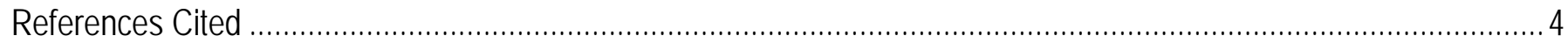

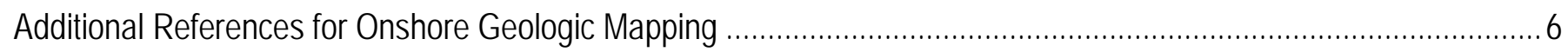




\section{Offshore Geology and Geomorphology from Point Piedras Blancas to Pismo Beach, San Luis Obispo County, California}

By Janet T. Watt, Samuel Y. Johnson, Steven R. Hartwell, and Michelle Roberts

\section{Introduction}

Marine geology and geomorphology were mapped along the continental shelf and upper slope between Point Piedras Blancas and Pismo Beach, California. The map area is divided into the following three (smaller) map areas, listed from north to south: San Simeon, Morro Bay, and Point San Luis (see index map on sheets 1, 3, 5). Each smaller map area consists of a geologic map (sheets $1,3,5$ ) and the corresponding geophysical data that support the geologic mapping. Each geophysical data sheet includes shaded-relief multibeam bathymetry (fig. 1 on sheets 2, 4, 6), seismic-reflection-survey tracklines (fig. 2 on sheets 2, 4, 6), and residual magnetic anomalies (fig. 3 on sheets 2, 4, 6), as well as a smaller version of the geologic map (fig. 4 on sheets $2,4,6$ ) for reference. Although the geologic maps are presented here at 1:35,000 scale, map interpretation was conducted at scales of between 1:6,000 and 1:12,000.

\section{Map Units}

Offshore geologic units were delineated on the basis of integrated analysis of adjacent onshore geology (see “Additional References for Onshore Geologic Mapping” list), seafloor-sediment and rock samples (Reid and others, 2006; Pacific Gas and Electric Company, 2011), multibeam bathymetry and backscatter imagery, magnetic data (Langenheim and others, 2009, 2012; Sliter and others, 2009), and high-resolution seismic-reflection profiles (Sliter and others, 2009). To maintain onshore-to-offshore consistency, map-unit symbols for the Mesozoic and Tertiary units reflect the published onshoremapping usage. If no onshore-equivalent unit exists, as is the case with the Quaternary units, the mapunit symbols are made up of letters that indicate the following: the Period, usually followed by "m" for marine sediment; the predominant sediment type; and, finally, a geomorphic descriptor, if applicable.

Nearshore and inner shelf deposits are predominantly sand (Qms), as determined by seafloor sampling (Reid and others, 2006). These sandy-shelf areas locally include coarser grained units such as channel deposits (Qmc), rills (Qmr), and sorted bedforms (Qmss; Trembanis and Hume, 2011). Unit Qmss typically exists as erosional lags in scour depressions whose contacts with horizontal sand sheets of unit Qms usually are relatively sharp but, less commonly, are diffuse. These scour depressions, which generally form irregular to lenticular exposures that have abrupt landward contacts with bedrock, typically are a few tens of centimeters deep and range in size from a few tens of meters to more than 1 $\mathrm{km}^{2}$. Such scour depressions are common along this stretch of the California coast (see, for example, Cacchione and others, 1984; Hallenbeck and others, 2012), where offshore sandy sediment is relatively thin (and, thus, is unable to fill the depressions) owing to low sediment supply and also to erosion and transport of sediment during large northwest winter swells.

Inner shelf deposits (predominantly sand) grade to finer grained (mud and sand) outer shelf (Qmsf) and slope (Qmsl) deposits at depths greater than $70 \mathrm{~m}$. The boundary between units Qms and Qmsf was determined on the basis of seafloor-sediment samples (Reid and others, 2006), as well as interpretation of multibeam backscatter imagery. This boundary likely shifts seaward or landward as a result of seasonal- to annual- to decadal-scale cycles in sediment supply, sediment transport, and wave 
climate. These shelf and slope deposits locally contain pockmarks (Qmp), hummocky relief (Qmsh), and landslide deposits (QIs). Landslide deposits may represent various forms of submarine sediment instabilities, including slumps, slides, and collapse depressions.

Where an older unit (typically bedrock) is overlain by a thin (less than $2 \mathrm{~m}$ ) Quaternary deposit, a composite geologic unit is mapped; the composite unit, shown with a stipple pattern on the older unit, is designated by a composite label indicating both the overlying sediment cover and the lower (older) unit, separated by a slash (/). For example, Qms/Tus indicates that a thin sheet of Qms overlies Tus. Such units are recognized on the basis of high backscatter, low relief, continuity with moderate- to highrelief bedrock outcrops, and (in most cases) high-resolution seismic-reflection data. The overlying sediment is interpreted as an ephemeral layer that may or may not be continuously present, depending on storms, seasonal and (or) annual patterns of sediment movement, or longer term climate cycles.

Sea level was approximately 120 to 130 m lower during the Last Glacial Maximum (about 21 ka; see, for example, Lambeck and Chappell, 2001; Gornitz, 2009). This approximate depth corresponds to the modern shelf break, a lateral change from the gently dipping $\left(0.8^{\circ}\right.$ to $\left.1.0^{\circ}\right)$ outer shelf to the slightly more steeply dipping (about $1.5^{\circ}$ to $2.5^{\circ}$ ) upper slope in the central and northern parts of the map area. South of Point San Luis in San Luis Bay (sheets 5, 6), deltaic deposits offshore of the mouth of the Santa Maria River (11 km south of the map area) have prograded across the shelf break and now form a continuous low-angle (about $0.8^{\circ}$ ) ramp that extends to water depths of more than $160 \mathrm{~m}$. The shelf break defines the landward boundary of slope deposits $(\mathrm{Qmsl})$. North of Estero Bay, the shelf break is characterized by a distinctly sharp slope break that is mapped as a landslide headscarp above landslide deposits (QIs) (sheets 1, 2). Multibeam imagery and seismic-reflection profiles across this part of the shelf break show evidence of slope failure, such as slumping, sliding, and soft-sediment deformation, along the entire length of the scarp. Notably, this shelf-break scarp corresponds to a west splay of the Hosgri Fault that dies out just north of the scarp, suggesting that faulting is controlling the location (and instability) of the shelf break in this area.

Lithologies of Tertiary and older seafloor bedrock units were determined on the basis of seafloor samples where available; otherwise, they were interpreted on the basis of their correlation to onshore geology, using their seafloor texture visible in multibeam imagery in addition to their magnetic character. Qms Tertiary units mapped in the offshore include rocks of the Obispo, Monterey, and Pismo Formations. The rhythmically bedded Monterey and Pismo Formations are characterized by their distinctive seafloor texture in multibeam imagery; in addition, they are relatively nonmagnetic. These rocks are underlain by, or are in fault contact with, Jurassic and Cretaceous basement that consists of rocks of either the two unnamed sandstone units (Ksl, Kslc), an unnamed graywacke unit (KJug), the Franciscan Complex (KJf), or the Coast Range ophiolite (Jo). These older units often are characterized by irregular, lumpy seafloor texture and complex magnetic signatures, owing to the highly deformed nature of the variably magnetic rocks.

Certain Mesozoic and Tertiary basement rocks, including ultramafic rocks of the Coast Range ophiolite Jo) and diabase and basalts of the Obispo Formation (Tod), are highly magnetic, making highresolution magnetic data (fig. 3 on sheets 2, 4, 6) an important mapping tool. Although metavolcanic rocks within the Franciscan Complex in this map area apparently are not magnetic, serpentinite is. Serpentinite, which is derived from the Coast Range ophiolite and is associated with the Franciscan Complex, commonly forms elongate magnetic bodies along fault zones and, thus, can assist in fault mapping.

\section{Faults and Folds}

Faults and folds shown on these maps are near-surface (upper about $200 \mathrm{~m}$ ) structures that are mapped primarily on the basis of interpretation of minisparker seismic-reflection data (tracklines shown 
in fig. 2 on sheets 2, 4, 6; see also, Sliter and others, 2009). These fault and fold interpretations were further modified on the basis of multibeam imagery and magnetic data; these laterally continuous datasets allow for more accurate interpolation of structures between the seismic-reflection profiles. However, we do not infer fault activity from these data, as we have no direct age data for surficial sediments.

Offshore faults and folds are symbolized as follows: a solid line is used where the location is certain; a dashed line, where the location is inferred; and a dotted line, where the location is concealed. In addition, queries are added where the existence of a feature is questionable. A fault or fold is mapped as inferred when its location is determined by interpolating between seismic-reflection profiles, as well as in bedrock outcrops where a lineament exists in the multibeam imagery but where clear evidence of fault offset or folded strata is lacking. A fault or fold is mapped as concealed where it can be identified in seismic-reflection data but where no surface deformation is apparent in either multibeam imagery or seismic-reflection data. However, it is important to note that, in areas where multibeam imagery does not exist, a fault or fold mapped as concealed may, in fact, have surface expression that is at a scale undetectable in the seismic-reflection data alone. Therefore, it is possible that the location of a fault or fold mapped as concealed may be just as accurate as that of a fault or fold whose location is mapped with more certainty (that is, with a solid or dashed line).

Magnetic data are particularly useful in guiding structural interpretations where massive Mesozoic bedrock is at or near the seafloor surface because, in these areas, seismic-reflection data often are poor owing to lack of penetration. Such is the case in the nearshore areas from Point Piedras Blancas to Shell Beach, which, with the exception of sediment-covered areas in central Estero Bay, are characterized by bedrock outcrops of predominantly Mesozoic basement rocks that are composed of variably magnetic rock types. Magnetic anomalies represent local spatial variations in the Earth's magnetic field that indicate the distribution of magnetic minerals_-primarily magnetite - in the underlying rocks. In many cases, the volume content of magnetic minerals can be related to rock type, and so it follows that abrupt spatial changes in the amount of magnetic minerals commonly mark lithologic or structural boundaries that would not be detectable in seismic-reflection data alone. For example, the Shoreline Fault is not detectable in seismic-reflection data but, rather, is mapped on the basis of correlation of magnetic-anomaly gradients, as well as on seafloor scarps visible in multibeam imagery.

\section{Regional and Local Tectonics}

This map area, which encompasses part of the Los Osos structural domain, lies on the east flank of the offshore Santa Maria Basin (McCulloch, 1987; Lettis and others, 2004), within the broader Pacific-North American plate transform margin. The Los Osos domain is characterized by a series of onshore, northwest-trending, fault-bounded basins and ranges that extend offshore, where they are partly covered by marine sediment and are truncated by the northwest-striking, right-lateral Hosgri Fault. The Hosgri Fault is an approximately 170-km-long (or longer?) right-lateral strike-slip fault (Petersen and others, 2008) that has an inferred Quaternary slip rate of 1 to 3 mm/yr (Hanson and Lettis, 1994; Hanson and others, 2004).

The shallow (upper $200 \mathrm{~m}$ ) structure of the Hosgri Fault, as revealed in high-resolution seismicreflection data, is a vertical fault zone that offsets the seafloor in numerous locations and that has many bends in strike that result in localized areas of uplift and subsidence. The map on sheet 1 shows the Hosgri Fault as being continuous with the onshore San Simeon Fault, and interpretation of highresolution seismic-reflection data (tracklines shown in fig. 2 on sheet 2) provides compelling evidence that this is the case (Johnson and Watt, 2012). This interpretation contrasts with previous interpretations (Pacific Gas and Electric Company, 1988; Lettis and others, 1990; Hanson and others, 2004) that 
showed the Hosgri Fault as ending just north of Point Estero, with slip transferring to the San Simeon Fault through a releasing right step. Note that previous interpretations considered the stepover and its associated pull-apart basin to be a barrier to earthquake rupture, and so our detailed mapping indicating that no Hosgri-to-San Simeon stepover exists has important implications for earthquake hazards (for a more detailed discussion, see Johnson and Watt, 2012).

Both the Los Osos and Shoreline Faults, which converge with the Hosgri Fault within the map area, are part of a broader fault system within the central Coast Ranges. The Los Osos Fault, as imaged with multibeam and high-resolution seismic-reflection data, forms a west-northwest-striking zone (1 to 3 $\mathrm{km}$ wide) of near-vertical faulting. Three distinct strands (north, central, and south) are evident on shallow seismic-reflection profiles. The Shoreline Fault, first recognized as a northwest-striking, vertical zone of earthquake hypocenters that parallels the coastline (Hardebeck, 2010), is expressed on the seafloor as a series of discontinuous, en echelon lineations and scarps visible in multibeam imagery. Detailed marine and airborne (helicopter) magnetic data also reveal a linear trend of magnetic anomalies, the edges of which are coincident with (or parallel to) the surface expression of the Shoreline Fault.

\section{Acknowledgments}

Funding for this work was provided by the U.S. Geological Survey (USGS) Coastal and Marine Geology Program, USGS Geology and Geophysics Program, and Pacific Gas and Electric Company (PG\&E) through a Collaborative Research and Development Agreement (CRADA). We thank Roberto Anima, Jeff Beeson (Oregon State University), Mike Boyle, Jackson Currie, Jamie Grover, Pat Hart, Gerald Hatcher, Larry Kooker, Daniel Scheirer, Ray Sliter, George Tate, Peter Triezenberg, and Robert Wyland (all USGS, unless otherwise noted) for assistance in collection of USGS seismic-reflection and marine magnetic data. Thanks to Theresa Fregoso (USGS) for GIS support. We also thank Rikk Kvitek and the California State University, Monterey Bay, Seafloor Mapping Lab for providing high-quality bathymetric-mapping datasets. We would like to thank the PG\&E-USGS CRADA research team, and Russell Graymer and Victoria Langenheim (both USGS), specifically, for their scientific collaboration and stimulating discussions. The insightful and constructive reviews by Jamie Conrad and Carl Wentworth (both USGS) greatly improved these maps.

\section{References Cited}

Cacchione, D.A., Drake, D.E., Grant, W.D., and Tate, G.B., 1984, Rippled scour depressions of the inner continental shelf off central California: Journal of Sedimentary Petrology, v. 54, p. 1,280-1,291.

Friday, D.Z., Taylor, L.A., Eakins, B.W., Carignan, K.S., Grothe, P.R., Lim, E., and Love, M.R., 2011, Digital elevation models of Port San Luis, California-Procedures, data sources, and analysis:

National Oceanic and Atmospheric Administration National Geophysical Data Center, Coastal DEMs, accessed December 2011, at http://www.ngdc.noaa.gov/mgg/coastal/coastal.html.

Gornitz, V., 2009, Sea level change, post-glacial, in Gornitz, V., ed., Encyclopedia of paleoclimatology and ancient environments: Springer, Encyclopedia of Earth Sciences Series, p. 887-893.

Hall, C.A., 1973a, Geologic map of the Morro Bay South and Port San Luis quadrangles, San Luis Obispo County, California: U.S. Geological Survey Miscellaneous Field Studies Map MF-511, scale $1: 24,000$.

Hall, C.A., 1974, Geologic map of the Cambria region, San Luis Obispo County, California: U.S. Geological Survey Miscellaneous Field Studies Map MF-599, scale 1:24,000.

Hall, C.A., 1976, Geologic map of the San Simeon-Piedras Blancas region, San Luis Obispo County, California: U.S. Geological Survey Miscellaneous Field Studies Map MF-784, scale 1:24,000. 
Hallenbeck, T.R., Kvitek, R.G., and Lindholm, J., 2012, Rippled scour depressions add ecologically significant heterogeneity to soft-bottom habitats on the continental shelf: Marine Ecology Progress Series, v. 468, p. 119-133.

Hanson, K.L., and Lettis, W.R., 1994, Estimated Pleistocene slip rate for the San Simeon fault zone, south-central coastal California, in Alterman, I.B., McMullen, R.B., Cluff, L.S., and Slemmons, D.B., eds., Seismotectonics of the central California Coast Ranges: Geological Society of America Special Paper 292, p. 133-150.

Hanson, K.L., Lettis, W.R., McLaren, M.K., Savage, W.U., and Hall, N.T., 2004, Style and rate of Quaternary deformation of the Hosgri Fault Zone, offshore south-central coastal California, in Keller, M.A., ed., Evolution of sedimentary basins/offshore oil and gas investigations-Santa Maria province: U.S. Geological Survey Bulletin 1995-BB, 37 p., available at http://pubs.usgs.gov/bul/1995/bb/.

Hardebeck, J.L., 2010, Seismotectonics and fault structure of the California Central Coast: Bulletin of the Seismological Society of America, v. 100, p. 1,031-1,050.

Hartwell, S.R., Finlayson, D.P., Dartnell, P., and Johnson, S.Y., 2013, Bathymetry and acoustic backscatter-Estero Bay, California: U.S. Geological Survey Open-File Report 2013-1225, available at http://pubs.usgs.gov/of/2013/1225/.

Johnson, S.Y., and Watt, J.T., 2012, Influence of fault trend, bends, and convergence on shallow structure and geomorphology of the Hosgri strike-slip fault, offshore central California: Geosphere, v. 8, no. 6, 25 p.

Lambeck, K., and Chappell, J., 2001, Sea level change through the last glacial cycle: Science, v. 292, p. 679-686, doi:10.1126/science.1059549.

Langenheim, V.E., Jachens, R.C., and Moussaoui, K., 2009, Aeromagnetic survey map of the central California Coast Ranges: U.S. Geological Survey Open-File Report 2009-1044, available at http://pubs.usgs.gov/of/2009/1044/.

Langenheim, V.E., Watt, J.T., and Denton, K.M., 2012, Magnetic map of the Irish Hills and surrounding areas, San Luis Obispo County, central California: U.S. Geological Survey Open-File Report 2012-1080, scale 1:24,000, available at http://pubs.usgs.gov/of/2012/1080/.

Lettis, W.R., DiSilvestro, L., Hanson, K.L., and Shiller, G.I., 1990, The San Simeon/Hosgri pull-apart basin-Implications for late Quaternary activity on the Hosgri Fault Zone, in Lettis, W.R., Hanson, K.L., Kelson, K.I., and Wesling, J.R., eds., Neotectonics of the south-central coastal California: Friends of the Pleistocene, Pacific Cell, 1990 Fall Field Trip Guidebook, p. 91-138.

Lettis, W.R., Hanson, K.L., Unruh, J.R., McLaren, M., and Savage, W.U., 2004, Quaternary tectonic setting of south-central coastal California, in Keller, M.A., ed., Evolution of sedimentary basins/offshore oil and gas investigations-Santa Maria province: U.S. Geological Survey Bulletin 1995-AA, 24 p., available at http://pubs.usgs.gov/bul/1995/aa/.

McCulloch, D.S., 1987, Regional geology and hydrocarbon potential of offshore central California, in Scholl, D.W., Grantz, A., and Vedder, J.G., eds., Geology and resource potential of the continental margin of western North America and adjacent oceans-Beaufort Sea to Baja California: Houston, Tex., Circum-Pacific Council for Energy and Mineral Resources, Earth Science Series, v. 6., p. 353-401.

National Oceanic and Atmospheric Administration National Geophysical Data Center, 2011, U.S. coastal relief model, vol. 6-Southern California: National Oceanic and Atmospheric Administration National Geophysical Data Center, U.S. Coastal Relief Model, accessed December 2011, at http://www.ngdc.noaa.gov/mgg/coastal/grddas06/grddas06.htm.

Pacific Gas and Electric Company, 1988, Final report of the Diablo Canyon long-term seismic program: U.S. Nuclear Regulatory Commission, Docket nos. 50-275 and 50-323. 
Pacific Gas and Electric Company, 2011, Report on the analysis of the Shoreline Fault Zone, central coastal California: Pacific Gas and Electric Company, Report to the U.S. Nuclear Regulatory Commission, available at http://www.pge.com/myhome/edusafety/systemworks/dcpp/shorelinereport/.

Petersen, M.D., Frankel, A.D., Harmsen, S.C., Mueller, C.S., Haller, K.M., Wheeler, R.L., Wesson, R.L., Zeng, Y., Boyd, O.S., Perkins, D.M., Luco, N., Field, E.H., Wills, C.J., and Rukstales, K.S., 2008, Documentation for the 2008 update of the United States National Seismic Hazard Maps: U.S. Geological Survey Open-File Report 2008-1128, 61 p., available at http://pubs.usgs.gov/of/2008/ $1128 /$.

Reid, J.A., Reid, J.M., Jenkins, C.J., Zimmerman, M., Williams, S.J., and Field, M.E., 2006, usSEABED -Pacific Coast (California, Oregon, Washington) offshore surficial-sediment data release: U.S. Geological Survey Data Series 182, available at http://pubs.usgs.gov/ds/2006/182/.

Sliter, R.W., Triezenberg, P.J., Hart, P.E., Watt, J.T., Johnson, S.Y., and Scheirer, D.S., 2009, Highresolution seismic-reflection and marine magnetic data along the Hosgri Fault Zone, central California: U.S. Geological Survey Open-File Report 2009-1100, version 1.1, available at http://pubs.usgs.gov/of/2009/1100/.

Trembanis, A.C., and Hume, T.M., 2011, Sorted bedforms on the inner shelf off northeastern New Zealand-Spatiotemporal relationships and potential paleo-environmental implications: Geo-Marine Letters, v. 31, p. 203-214.

U.S. Geological Survey and California Geological Survey, 2010, Quaternary fault and fold database of the United States: U.S. Geological Survey database, accessed January 3, 2012, at http://earthquake.usgs.gov/hazards/qfaults/.

\section{Additional References for Onshore Geologic Mapping}

Dibblee, T.W., Jr., comp., 1971, Geologic map of the Adelaida quadrangle, California, plate 1 in Geologic maps of seventeen 15-minute quadrangles (1:62,500) along the San Andreas fault in vicinity of King City, Coalinga, Panoche Valley, and Paso Robles, California, with index map: U.S. Geological Survey Open-File Report 71-87, scale 1:62,500.

Hall, C.A., 1973b, Geology of the Arroyo Grande 15' quadrangle, San Luis Obispo County, California: California Division of Mines and Geology Map Sheet 24, scale 1:48,000.

Hall, C.A., and Prior, S.W., 1975, Geologic map of the Cayucos-San Luis Obispo region, San Luis Obispo County, California: U.S. Geological Survey Miscellaneous Field Studies Map MF-686, scale $1: 24,000$.

Weber, G.E., 1983, Geological investigation of the marine terraces of the San Simeon region and Pleistocene activity on the San Simeon fault zone, San Luis Obispo County, California: U.S. Geological Survey Final Technical Report, Contract 14-08-00001-18230, 66 p. 